\title{
Música, memórias e trânsitos decoloniais na Amazônia Acriana
}

\author{
Música, memorias y trânsitos decoloniales en la Amazonía Acriana \\ Music, memories and decolonial transits in Amazônia Acriana
}

\author{
Ma. Maria Cristina Lobregat ${ }^{1}$ \\ Arthur José de Souza Martins ${ }^{2}$ \\ Ma. Joana de Oliveira Dias ${ }^{3}$
}

\begin{abstract}
Resumo
Este texto traduz algumas experiências vividas no projeto intitulado "Memórias Musicais vivas na Amazônia Acriana" e desenvolvido pelo grupo de pesquisa "Azougue: ateliê de pesquisa e extensão em artes", cujo objetivo consiste em cartografar saberes que envolvem a prática musical e a vida de pessoas que compõem este heterogêneo cenário, no qual a prática musical e a vida são intimamente entrelaçadas. Franscisco Dalerbã é conhecido como "Chiquinho da Guitarra". Instrumentista, arranjador, cantor e compositor, Seu Chiquinho desenvolveu seu estudo musical aliado às demais práticas culturais. A trajetória autodidata de estudo e aprendizagem musical de Seu Chiquinho cria uma forma de relação com a escuta e com o instrumento musical extremamente rica. Entre os dilemas da distinção entre o músico e o tocador, a perspectiva de Seu Chiquinho, hoje aos 67 anos, desloca o muro construído de tijolos de letramento para instituir um território onde existe uma estética e uma forma de relacionamento com a arte criada a partir da leitura do mundo, amparada a partir da escuta. Diante das diferentes adversidades traremos uma análise que envolve e percebe o homem amazônico e suas aprendizagens diante das representações produzidas pelo "outro" a partir do imaginário e desconstruiremos as percepções vindas de uma imagem que ofusca a realidade vivenciada no seringal no que consiste a expressão musical.
\end{abstract}

Palavras-Chave: Capital cultural; decolonialidade; oralidade; representação.

\section{Resumen}

El texto traduce algunas experiencias vividas en el proyecto titulado "Memorias Musicales vivas en la Amazonia Acriana" y desarrollado por el grupo de investigación "Azougue: taller de investigación y extensión en artes", cuyo objetivo consiste en cartografiar saberes que envuelven la práctica musical y la vida de la gente que compone este heterogéneo escenario, en el que la práctica musical y la vida están íntimamente entrelazadas. Francisco Dalerbã es conocido como "Chiquinho de la guitarra". Instrumentista, arreglador, cantante y compositor, señor Chiquinho desarrolló su estudio musical aliado a las demás prácticas culturales. La trayectoria autodidacta de estudio y aprendizaje musical de señor chiquinho crea una forma de relación con la escucha y con el instrumento musical extremadamente rico. Entre los dilemas de la distinción entre el músico y el tocador, la perspectiva de señor chiquinho hoy a sus 67 años, desplaza el muro construido de ladrillos de letramento para instituir un territorio donde existe una estética y una forma de relación con el arte creado a partir de la lectura del mundo, amparada a partir de la escucha. Ante las diferentes adversidades traemos un análisis que involucra y percibe al hombre amazónico y sus aprendizajes ante las representaciones producidas por el otro a partir del imaginario y deconstruimos las percepciones venidas de una imagen que ofusca la realidad vivenciada en el seringal en lo que consiste en la expresión musical.

\footnotetext{
${ }^{1}$ Mestra em Letras: Linguagens e Identidades (UFAC); doutoranda pela Universidade Estadual do Oeste do Paraná - UNIOESTE; Foz do Iguaçu, Paraná, Brasil; cristina.lobregat@gmail.com.

${ }^{2}$ Graduando em Licenciatura em Música; Universidade Federal do Acre - UFAC; Rio Branco, Acre, Brasil; miudarthur@gmail.com.

${ }^{3}$ Mestra em Desenvolvimento Regional (UFAC); Docente no Instituto Federal do Acre - IFAC; Rio Branco, Acre, Brasil; joana.dias@ifac.edu.br.
} 
Palabras claves: Capital cultural; decolonialidad;oralidad; representación.

\begin{abstract}
This text refects some of the experiences of the Project entitled "Memórias Musicais vivas na Amazônia Acriana" and developed by the research group "Azougue: ateliê de pesquisa e extensão em artes", whose objective is to map knowledge that involves musical practice and the life of people who make up this heterogeneous scenario, in which musical practice and life are intimately intertwined. Franscisco Dalerbã is known as "Chiquinho Guitarman". Instrumentalist, arranger, singer and composer, Mister Chiquinho developed his musical study allied to the other cultural practices. Mister Chiquinho's self-taught trajectory of study and musical learning creates a form of relationship with listening and with the extremely rich musical instrument. Among the dilemmas of the distinction between the musician and the player, Mister Chiquinho's perspective, now 67 years old, moves the wall built of bricks of literacy to establish a territory where there is an aesthetic and a form of relationship with art created from his point of view, supported by listening. In the face of the different adversities we will bring an analysis that involves and perceives the Amazonian man and his learning before the representations produced by the "other" from the imaginary and deconstruct the perceptions coming from an image that obfuscates the reality experienced in the seringal in which the musical expression consists.
\end{abstract}

Keywords: Cultural capital; decoloniality; orality; representation.

\title{
1. Introdução
}

"Os sons são uma das formas através das quais as pessoas modelam a sua história, sua experiência." Alessandro Portelli

"Eu sei porque sei, não porque li." Sebastião Mota de Melo

Este texto traduz experiências vividas em um projeto desenvolvido pelo grupo de pesquisa "Azougue: ateliê de pesquisa e extensão em artes", vinculado à Fundação de Amparo à Pesquisa do Estado do Acre (FAPAC) e intitulado "Memórias Musicais vivas na Amazônia Acriana", cujo objetivo consiste em cartografar saberes que envolvem a prática musical e a vida de pessoas que compõem este heterogêneo cenário, no qual o fazer musical e a vida são intimamente entrelaçados.

Nosso encontro com a história oral transcende o debruçar-se sobre uma metodologia, ao passo que impulsiona a compreensão da importância da experiência e da memória como condição humana nas relações, vivências e práticas culturais. Nesse contexto, buscar compreender as relações do ser humano com sua cultura em suas expressões artísticas dependia de ouvir as histórias de vida de músicos/tocadores.

O exercício de escuta das narrativas colhidas em entrevistas está orientado no sentido de tomá-las como fonte de conhecimentos credíveis (ALBUQUERQUE, 2011; LÓPEZ, 2009), enquanto o exercício da escrita é uma trajetória de atento desvio às distinções de raça e 
de classe e suas insistentes faces e categorias. Uma nova forma de ver o sujeito, diante de sua história subjetiva e, ao mesmo tempo, ancorada na coletividade.

Alessandro Portelli registra a importância da individualidade nas narrativas orais e no trabalho com a memória, sendo ela a essencialidade do indivíduo longe de caracterizar-se como "um depósito de dados" (PORTELLI, 1981, p.16), razão pela qual esta análise aproxima-se da experiência. Lembrar é uma atividade essencialmente humana que pode tomar novos significados quando registrada, salientando assim a utilização da linguagem escrita dentro de uma sociedade ligada ao valor que a palavra escrita possui. Está posto, portanto, o desafio de distanciar-se dos discursos instituídos a partir de escrituras consagradas por apresentarem fatos, dados, causas e consequências, e assim usam a maquiagem de "verdade".

Ao passo que a memória individual cria um cenário de experiências também coletivas, sociais, temos então subsídio para discutir sobre Amazônias que fogem do imaginário hegemônico moderno colonial. Com o texto, queremos nos contrapor às ideias que definem um lugar de dominação nos discursos feitos pelos colonizadores que ecoam naqueles que ainda veem uma Amazônia singular, distante, isolada e atrasada.

Esse caminho que percorremos, trouxe-nos a narrativa oral do Senhor Francisco Dalerbã e suas experiências logo no início do artigo. Vale salientar que nas narrativas encontramos como foi constituída a sua aprendizagem, a partir da trajetória de vida nos seringais onde ele viveu até a juventude, em contato com a música, seguida de um deslocamento para o meio urbano na cidade de Rio Branco. O artista narra sua aprendizagem de forma autodidata diante da sua construção identitária como profissional da música.

Em um segundo momento do artigo, traremos a discussão sobre o capital cultural cunhado por Pierre Bourdieu, ressaltando que os grupos sociais hegemônicos instituem a cultura erudita como parâmetro e assim criam o contraste com quaisquer outras manifestações culturais, como as vividas por Seu Chiquinho, nascidas das sociabilidades e interação dos grupos em suas espacialidades e temporalidades. A valorização desses saberes outros será colocada em evidência, bem como as influências externas que produzem uma aprendizagem interna.

Por fim, traremos Durval Muniz, Certeau, Glissant e Mignolo para seguir a (des)aprendizagem e tornar constantes as indagações que percorrem nossas pesquisas, trazem sempre a inquietação e nos situam nos trânsitos decoloniais que as narrativas instigam.

\section{Diálogos e experiências: "sola uma aí, Chiquinho"}


Para narrar a experiência de convívio com Seu Chiquinho trazemos à tona a memória de Arthur José, também músico, quando o acompanhou em uma "tocada no Quinarí" no primeiro semestre de 2014, na quadra de uma escola, onde se apresentavam com a banda “Caravana do Pecado". O grupo acompanhava o Sr. Leodigar Prado, conhecido como Léo do Bandolim, que solava lambadas, boleros, xotes, valsas, sambas, marchas e rancheiras. Próximo ao fim da festa, o Sr. Leodigar (um dos músicos), já cansado, diz: "Sola uma aí, Chiquinho", este toca "Lambada do Rei”, sucesso de Vieira e Seu Conjunto (VIEIRA, 1980). O salão "pegou fogo", casais dançavam e a alegria contagiava o lugar e Arthur José fica admirado pela habilidade de Seu Chiquinho ao se relacionar com o instrumento musical.

A partir daí foram muitos encontros em finais de semana no "Poeirinha" (Figura 1), uma casa de shows mantida de forma independente por uma associação da chamada terceira idade, onde o Seu Chiquinho atua desde 2005 e localizada no bairro Aeroporto Velho, na capital Rio Branco (MARTINS, 2015).

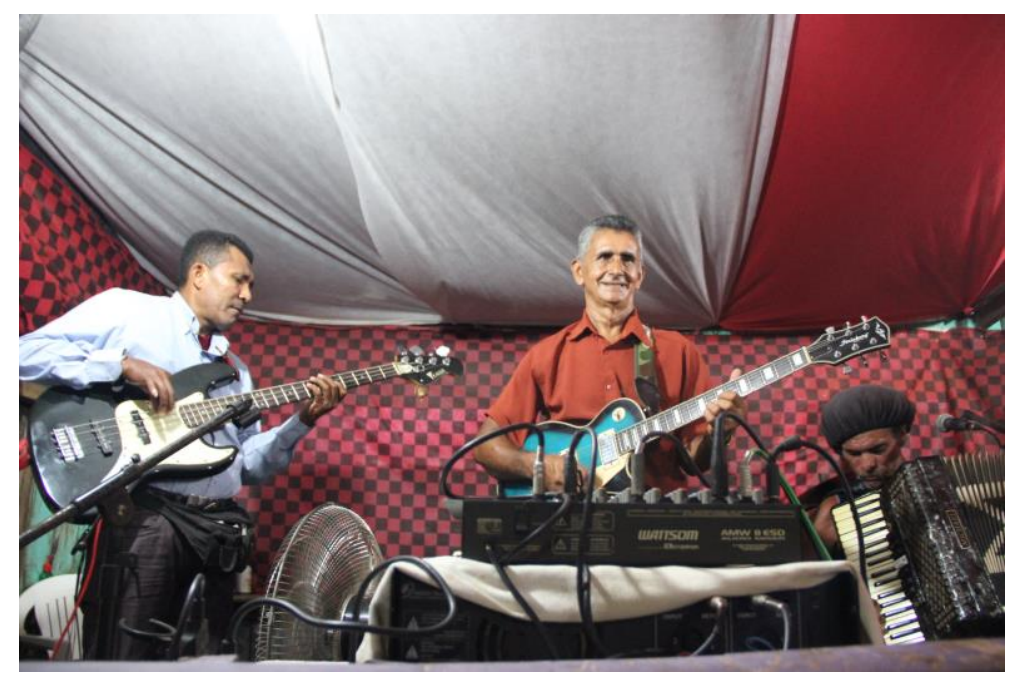

Figura 1 - Chiquinho da Guitarra ao centro, em apresentação no Poeirinha no Bairro Aeroporto Velho. Fonte: Acervo de Elisson Magalhães (2016).

A entrevista com seu Chiquinho, cujas narrativas são apresentadas neste texto, ocorreu três anos depois, no dia 10 de março de 2017, no bairro Airton Sena, em Rio Branco, na casa de sua mãe, que durante toda a entrevista permaneceu próxima. A entrevista foi agendada em um encontro casual na rua principal do bairro Aeroporto Velho.

Franscisco Dalerbã hoje é conhecido como "Chiquinho da Guitarra". Ao discorrer sua narrativa, Seu Chiquinho apresenta-se como Chiquinho do violão, o cantor, o seringueiro, o

\footnotetext{
${ }^{4}$ A "tocada" é um termo utilizado por músicos/tocadores como uma gíria que se refere ao ato de tocar, consiste em uma apresentação musical. O Quinarí é o nome popular do município de Senador Guiomard, vizinho da capital Rio Branco no Acre.
} 
agricultor, o filho, o irmão, o funcionário da prefeitura. E nos ensina como se constituiu na sua trajetória de vida como instrumentista, arranjador, cantor, pesquisador e compositor.

Nasceu no dia 14 de junho de 1950 no Rio Muru, município de Tarauacá no Estado do Acre. "Nasceu e se criou" no seringal, onde morou até 1988, quando foi morar na capital Rio Branco. O contato com a música deu-se ainda na infância quando, escondido, dedilhava os primeiros solos no violão do seu pai, também instrumentista e cantor.

\begin{abstract}
Eu, na época que eu queria tocar violão, minha mãe e meu pai não queriam, minha mãe queria que eu aprendesse a ler, estudar... eu não queria! Pra mim... A minha arte... de viver, de aprender, era tocar violão... Eu tocava escondido, antes da minha mãe liberar mais meu pai, era escondido. Eu pegava o violão do meu pai, ficava tocando escondido, minha irmã ficava pastorando. "Quando tu vê qualquer zuada que é a mamãe ou o papai tu me diz que eu já guardo o violão". Porque eles não queriam, eles queriam que eu aprendesse a ler e eu não queria! Pra mim aquilo não ia servir de nada, pra mim era uma coisa que não interessava. Agora, tocar violão, era o que eu mais queria. Passava a noite numa festa, o povo que tocava nesse tempo era mais solo de música, tinha que ser uma música decente. Eu ficava do lado ali, só ouvindo ali, gravando, né? Na memória... Mas não tocava, não podia pegar, minha mãe insistia pra mim dormir, eu ia pra dentro do quarto, mas de lá, eu ficava olhando na brecha, me levantava e ficava olhando, e assim até que a minha mãe achou mais meu pai, que não podiam dar jeito, aí liberou pra mim tocar o violão, aí eu comecei a tocar o violão e cantar, era um grande cantador assim no seringal.
\end{abstract}

Eu acho, eu tenho certeza que foi um dom, que eu já trouxe de nascença. Porque quando eu comecei a entender de instrumento, ver alguém tocar, aquilo me chamou tanto a atenção, desde de dentro de mim... Chamou uma atenção tão grande, que eu era apaixonado por isso, ainda hoje eu tenho, eu sou fanático em instrumento de corda (Francisco Dalerbã em 10/03/2017).

Sentado na varanda ao lado da mãe, Seu Chiquinho narra que sempre teve interesse pela música, de maneira subjetiva ela sempre esteve presente "dentro de si”. Ele nos dá pistas desse seu envolvimento como algo que havia nascido com ele, como uma divindade. A narrativa envolve relações sociais, a família e outros grupos em um cotidiano que ele teve como experiência, e que Seu Chiquinho traz à tona para mostrar o fato de que a afinidade com a música nasceu também no seu ambiente de relações. Embora, em sua memória, ele relembre a recusa dos pais e a preferência que tinham pelo conhecimento institucionalizado/escolar em sua educação.

Quando situa sua aprendizagem musical, o espaço da narrativa é a casa, que é moradia, escola, palco, é festa. O tempo é o da infância, o do dedilhado escondido, da história de vida, é época. Este espaço-tempo da cultura é a ambiência para aprender, ouvindo, gravando na memória e olhando pela brecha os solos de música que davam sentido à arte de viver e de aprender que ele tanto aspirava, e que até hoje é sua paixão. 
É possível observar como a conversa de Arthur José com Seu Chiquinho torna-se uma oportunidade de revisitar sob uma nova perspectiva as histórias que Arthur aprendeu dos livros escolares sobre os seringais no Acre. Seu Chiquinho responde atencioso às perguntas sobre o seringal onde nasceu e tece suas memórias do Rio Muru.

Cortava seringa, eu nasci e me criei no seringal cortando seringa, comecei a andar na estrada mais meu pai, eu tinha nove anos de idade, aí com onze anos eu cortava seringa sozinho, duas estradas, cada uma com noventa seringa, cortava e colhia sozinho. Aí cortei até 1989, aí vim pra Tarauacá. Eu ainda morava no seringal, aonde eu morava, dava três dias de barco, subindo o rio, a gente vivia da agricultura. E sobre o rancho, a fartura no seringal é o que você pode colher, de tudo tem, da mata né, de bicho da mata. Você só compra o óleo, açúcar, essas coisas assim, mas carne não, tudo é da mata. A gente plantava mandioca, milho, arroz, cana, banana, abacaxi, o abacaxi de lá quando cresce, se você não escorar, ele quebra, ele não aguenta, quebra no pé do talo. (Francisco Dalerbã em 10/03/2017).

O seringal narrado por Seu Chiquinho é um território existencial próprio, revisitado na experiência do ato narrativo, marcando um tempo e um espaço que a partir da memória foram construídos. Portanto, não vem ao caso invocar os acervos de imagens e palavras que inventaram os seringais acrianos ancorados na estética amazonialista que governa nossas subjetividades: do vazio, distante, dependente (ALBUQUERQUE, 2016).

A narrativa segue, as curiosidades também. Diante disso surgem, na fala de Seu Chiquinho, as dificuldades enfrentadas para ter acesso aos instrumentos musicais, quando Arthur o questiona sobre isso.

Tinha que encomendar ao patrão. O patrão tinha que ver se o freguês tinha condição de pagar, de comprar o instrumento, porque se o freguês fosse devedor, o patrão não confiava. O rádio era difícil, só quem tinha um rádio, era só as pessoas de saldo mesmo, a vitrola tocada a corda. Era muito difícil, quem tinha rádio era os patrão, a gente chegava na margem e falava "vamos assistir o rádio", aquilo era uma novidade pra quem morava no seringal.

[...] Até que papai conseguiu comprar o rádio e eu também já fui ficando de maior, tomando conta das estradas, cortando seringa e já levava o rádio. Quando eu chegava da estrada a primeira coisa que eu ligava era o rádio, ficava ouvindo aqueles programas de música e ia aprendendo, aprendendo (Francisco Dalerbã em 10/03/2017).

A dificuldade para a aquisição de instrumentos era uma realidade na juventude deste músico, mas não o impedia de ter afinidade com a música. É necessário destacarmos que o tempo vivido por Seu Chiquinho da Guitarra é o grande feitor desta dificuldade, sendo que o espaço que imaginamos como seringal é isento deste evento. Estamos marcando um tempo, final dos anos 1960, quando os bens materiais não se popularizavam com facilidade devido ao 
aspecto econômico do país. Sendo assim, as dificuldades não estão diretamente ligadas ao “isolamento" geográfico do seringal, mas a uma realidade econômica brasileira.

Em sua trajetória de encontro com as expressões musicais, Seu Chiquinho narra que ouvia as melodias das rádios Rio Mar, Baré e Difusora Acriana. As referências musicais citadas em sua narrativa são: Teixeirinha, Gildo de Freitas e os trios de forró: os 3 do Nordeste, Trio Nordestino, Trio Mossoró, Trio Nortista, dentre outros. Um destaque na linguagem musical de seu Chiquinho é a influência de Dilermando Reis, violonista e compositor brasileiro da música instrumental.

\begin{abstract}
O solo, ele é muito difícil, você solar! Não é pra qualquer uma pessoa. O solo, professor nenhum ensina, você tem que aprender, decorar, tem que colocar na memória, é você mesmo se esforçar de fazer aquilo que você botou na memória, depois que fez isso, você vai procurar aquela música no seu instrumento, até dar certo. Quando eu não tava no trabalho, eu tava no violão. Ou tava no violão, ou ouvindo música, tirando aquelas notas, aqueles solos bonitos, sempre meu professor foi Deus e essas músicas que eu sempre ouvi. Eu nunca cheguei numa escola de música pra pegar uma lição de nenhum professor, até procurei, mas foi um dom que Deus me deu (Francisco Dalerbã em 10/03/2017).
\end{abstract}

O solo é o momento em que o músico, através da voz ou de um instrumento específico, executa determinado fragmento musical com destaque. "Música solada" é um termo recorrente no diálogo com músicos dessa geração e se refere à música instrumental. Seu Chiquinho cita entre os instrumentos mais usados como solistas a sanfona, o violão e o cavaquinho.

Em sua fala Seu Chiquinho demonstra como criou uma forma autodidata de estudo. A memorização das músicas que ouvia ao seu redor era seguida de uma internalização para só depois "passar a música" para seu instrumento, tarefa essa, que exige um nível de concentração, atenção e percepção apurado. Nessa forma de aprendizagem e aprimoramento praticada por seu Chiquinho e tantos outros músicos, conhecida como "tocar de ouvido", o músico entra em contato direto com o som, sem a mediação de um professor ou de um documento escrito (a partitura), ele torna-se mestre de si mesmo. $\mathrm{O}$ universo cultural onde o músico está inserido também desempenha grande papel na aprendizagem, através da interação e, principalmente, pela observação aliada à escuta. Afinal, é interessante notar como mais uma vez essa perspectiva descristaliza a ideia de isolamento que sombreia o rótulo "músico do seringal na Amazônia", pois ser autodidata não significa "aprender sozinho". Vale ressaltar também que a paisagem sonora acústica desempenha um papel crucial no desenvolvimento 
desta habilidade, em comparação à poluição sonora e o condicionamento do ouvido a mediadores eletroeletrônicos aos quais estamos habituados.

Diante da experiência autodidata de Seu Chiquinho, nos apoiamos na discussão de Lilliestam sobre os processos de aprendizagem musical de ouvido no qual nos alerta que:

\begin{abstract}
O ensino tradicional de música dá grande ênfase ao desenvolvimento da capacidade de dominar os códigos da escrita musical. Para a prática e perpetuação do repertório clássico, onde se almeja reproduzir as peças musicais tal qual o compositor idealizou, a escrita faz-se realmente indispensável. Porém, a hegemonia desse tipo de ensino tornou natural a noção de que o conhecimento em música reside na capacidade de ler notação musical e no domínio da teoria dessa tradição (LILLIESTAM, 1995 apud COUTO, 2008).
\end{abstract}

O ensino formal de música em grande parte cria uma espécie de fragmentação do ato de tocar, tornando abstratos fragmentos como o ritmo, melodia, harmonia, leitura, escrita, e, portanto, descola a experiência das demais práticas culturais da vida. Assim, cria uma espécie de individualismo e de enrijecimento do fazer musical. No contexto da colonialidade do saber, gera-se um confronto do músico aprendiz com sua própria trajetória de conhecimento e cultura, uma vez que ao sentar em "uma tocada" com outros músicos esses saberes estão presentes de forma integrada e regidos por valores outros, como o respeito, humildade e a convivência.

Levando em conta que a prática autodidata de "tocar de ouvido" é taxada como um atraso em relação ao estudo acadêmico e letrado da música, incorporamos a leitura de Marcelo Messina (2016) sobre este tipo de representação como um instrumento de dominação cultural, que justifica incursões violentas de uma "modernidade" que se manifesta de diferentes formas.

\footnotetext{
Frente a essa violência discursiva é possível propor uma interpretação alternativa e emancipatória do conceito de atraso: em outras palavras, o rótulo de lugar atrasado pode passar para uma apropriação e uma subversão política, em que a lentidão associada ao atraso não é incapacidade de manter o ritmo da modernidade, mas não-conformidade, antagônica, obstinada e militante com esse ritmo (MESSINA, 2016 p. 101).
}

$\mathrm{O}$ autor percebe a ressonância entre essa forma de resistência criativa e o conceito de desobediência epistêmica de Mignolo (2008) e nos conduz a mergulhar na lógica que Seu Chiquinho instaura em sua prática musical. Esse transitar decolonial traz questões pertinentes não só à música, mas também às demais linguagens artísticas. 


\section{Tocador ou músico: as representações envolvidas nos momentos de reconhecimento}

O amazonialismo, em seu "conjunto de narrativas formulado - desde epistemologias coloniais - sobre as gentes, culturas, línguas, sociedades, valores, crenças, fazeres ou práticas culturais em distintos territórios", produz subjetividades e delimita a Amazônia, homogênea e vazia de humanidades e culturas (ALBUQUERQUE, 2016 p. 78). Esse discurso, de maneira análoga, forja significados àquele que pensa sobre o que é ouvido e tocado por Seu Chiquinho, significados que não encontram referentes no mundo real.

As músicas que vibram na memória do entrevistado sacodem o imaginário sensível daqueles que não conhecem um seringal e, no correr de décadas, sofrem tentativas de silenciamento - epistemicídio - excluídas por serem vistas como expressões culturais externas ao que Bourdieu chama de "capital cultural” (BOURDIEU, 2008, p.17).

As lembranças de Seu Chiquinho, que viveu e tocou há décadas nas instituições representativas nas margens dos rios, chamaram atenção para o papel que a música ocupava naquele contexto de tempo e espaço e como eram capazes de conduzir os comportamentos sociais em nome de uma tradição que vinha de longe, mas que estava presente, simbolicamente, nas construções ideológicas de organização das comunidades.

A história de vida de Seu Chiquinho, tocador autodidata, reafirmou a importância da música como forma de comunicação, pois ela, muitas vezes proporcionou marcos nas trajetórias e experiências vividas.

Desse modo, esta seção se propõe a refletir sobre as afirmações simbólicas que envolvem o que chamamos de tocador e o que chamamos de músico. Como este artista se reconhece e é reconhecido hoje, e como era em décadas passadas? Qual o papel deste artista no contexto em que está inserido? São questões que, brevemente, traremos para a discussão, pensando sempre pelo campo simbólico e identitário deste profissional.

Durante a entrevista, Seu Chiquinho traz em sua fala um limiar identitário entre o músico e o tocador. A temática surge quando sua narrativa relaciona a experiência de aprender à experiência de ensinar, como uma partilha tecida em relações, inserida em uma lógica própria:

Eu admirava muito o Adolfo, rapaz, Pedacinho do Céu, aquele chorinho, ele tocava, aí eu ficava admirado, eu falava:

- Adolfo, rapaz, acho que eu não toco isso não.

- Toca porra!

Aí eu fiquei assim, eu toco! Eu vou tocar isso aqui, eu vou aprender isso aqui! Fui e gravei uma fita, os dois lados, eu tinha um gravador muito bom, 
fui e gravei uma fita dos dois lados, só Pedacinho do Céu, direto, direto, direto.

[...] Isso já foi por aqui, isso era em noventa e três, por ai assim. Aí botei no gravador, e peguei o violão, quando chegava naquela coisa que eu não fazia, dava pause lá é começava de novo. Diz ele que passou trinta dias pra aprender, o Adolfo. Eu em seis dias eu toquei ele todinho, tem aquela pontuação bonita que não é todo mundo que faz não, é preciso ter muita experiência pra fazer.

[...] um rapaz que morava lá no Calafate, ele tocava sempre pelo Senadinho ali, mais os meninos do Olívio, moreninho, ele veio morar no Novo Horizonte, eu morava no Calafate, aí se deu comigo, e disse:

- Rapaz, tu toca violão?

- Eu faço zuada ali...

- Então eu venho para cá pra tu me ensinar o Pedacinho do Céu.

Aí, eu digo tá! Ele veio, aí eu ensinava pra ele, e ele dizia:

- Ah, meu irmão, eu num aprendo não!

- Não, só vou deixar quando você tiver tocando ele direitinho!

Ele pelejava, eu solava o Pedacinho do Céu pra ele acompanhar, solava no cavaquinho, quando chegava, eu dizia, não é aí, volte do começo, ele queria desistir... Hoje ele tá um maestro.

Tem uma lei que ampara os músicos, mas nóis não somos músicos, somos tocador, de qualquer maneira sem nóis, não tem festa, nóis tamo exercendo uma profissão de músico (Francisco Dalerbã em 10/03/2017).

Ao final desta fala, Seu Chiquinho expõe como essa lógica da partilha que permeia sua relação com a música e com os outros músicos não é a mesma daquela que define por lei a profissão de músico. Ele expõe em um tom de crítica a forma como sua capacidade de ensinar, dedilhar, solar não tem reconhecimento por não fazer parte de um campo escolar (BOURDIEU, 2008).

Além disso, nos alerta sobre questões que envolvem a formalização da profissão diante das instituições que proporcionam a condição de nomear o músico, em um contexto organizado e reconhecido pela sociedade, em diferentes territórios. A identidade dos tocadores é ressaltada na narrativa de vida, mas o conhecimento que possuem não é valorizado pelas instituições.

Tocador é aquele que não tem carteira, toca de ouvido, ele não é músico, é tocador como qualquer outro. Músico é quem lê partitura. Mas se você tirar a partitura da frente, ele não sabe mais o que fazer. E esse que toca com a música gravada aqui (faz movimento apontando para a cabeça, indicando a memória) ele tá com ela na mente, não precisa olhar pra nada, ele tá com a mente firmada ali no que tá fazendo, pra mim esse é o músico (Francisco Dalerbã em 10/03/2017).

Observamos que ele caracteriza os dois conceitos: o conceito de músico e o de tocador. Ao mesmo tempo em que ele respeita a qualidade daquele que lê partitura e que, na sua visão, é considerado músico, também traz um tom carregado de significado positivo em 
direção àquele que toca sem a partitura. Finaliza a fala considerando aquele que ele chama de "tocador" como "verdadeiro músico".

Nesse sentido seguimos com os estudos de Gerson Albuquerque sobre o amazonialismo, em sua interlocução com Bakhtin/Volochínov, para observar uma fronteira simbólica entre as expressões/conceitos que conferem sentido no universo de palavras, imagens e gestos significantes, e assim dão forma e existência às consciências individuais/coletivas (ALBUQUERQUE, 2016). Seu Chiquinho em sua fala nos remete à criação social de uma dicotomia, traçando as diferenças implicadoras como unidade significativa, ou melhor, o significado de ser tocador é diferente do significado de ser músico.

Isso implica nas práticas culturais que a música pode proporcionar em um ambiente produtivo e de expressão, como é o caso vivenciado por Seu Chiquinho, ao compor suas trilhas de sentidos alternativos nas quais ele supera as barreiras em sua expressão artística.

Sem incorporar qualquer timbre de inferioridade, ele diferencia sua prática daquela construída pelos que frequentam a instituição consolidada para se aprender. $\mathrm{O}$ vínculo do artista com a instituição oficial, participar dos rituais de leitura e escrita musical, receber uma certificação ou diplomação são normas que concretizam a importância da instituição para a identidade social de músico. A frequência ou não na escola de música traça uma separação identitária e atribui ao "outro" um reconhecimento. Nas palavras de seu Chiquinho esse reconhecimento passa pela carteira profissional e o amparo da lei.

A história de Seu Chiquinho nos remete à discussão de Bourdieu sobre a força de poder que há no capital cultural e, consequentemente, sobre a separação que há entre os conhecimentos eruditos, "acessíveis apenas aos detentores do manejo prático ou teórico de um conjunto refinado (...) dos códigos" (BOURDIEU, 1987, p.116), e o conhecimento popular que nasce a partir das expressões culturais, que naquele contexto possui grande valor por representar ao tocador a maior qualidade: "tocar de ouvido".

Esse diferencial de habilidade do tocador é exaltado por Seu Chiquinho, é o que o distingue de um músico de academia. Embora ele reconheça que há valor na prática de ler partituras, percebe um aprisionamento desse músico acadêmico àquilo que está no papel. Nesse caso, o músico que aprendeu a tocar a partir da observação e da relação social com a música, compreende que embora não lhe seja atribuído o título de músico, para ele e para o contexto de suas experiências, o "verdadeiro músico" é aquele que sabe tocar sem partitura, que toca "de cabeça e de ouvido". A partir da fala de Seu Chiquinho, o que é valorizado é a intimidade na relação com a música, que se dá essencialmente por meio do corpo. 
A partir de Bourdieu na obra "A distinção", que trata da cultura erudita e popular nas expressões musicais, mas uma análise em contexto europeu, é teorizado que a aceitação e "gosto" são fomento de um capital cultural, ou melhor: o gosto é uma criação do capital. A partir da pesquisa de Bourdieu, podemos traçar um paralelo em relação à superioridade reconhecida do músico que possui a instrução escolar e que se apropriou de conhecimentos só fornecidos por esta instituição. Para Bourdieu, em sua pesquisa, as classes tornam-se hierarquizadas a partir destes comportamentos e reconhecimentos sociais.

\begin{abstract}
Eis porque convém deter-se, em primeiro lugar, no efeito, sem dúvida, mais bem dissimulado da instituição escolar, ou seja, aquele que produz a imposição de títulos, caso particular do efeito de atribuição estatutária, positiva (enobrecimento) ou negativa (estigmatização), que todo grupo produz ao fixar os indivíduos em classes hierarquizadas. Diferentemente dos detentores de um capital cultural desprovido da certificação escolar que, a todo o momento, podem ser intimidados a apresentar seus comprovantes, por serem identificados apenas pelo que fazem, simples filhos de suas obras culturais, os detentores de títulos de nobreza cultural - neste aspecto, semelhantes aos detentores de títulos nobiliárquicos, cujo ser, definido pela fidelidade a um sangue, solo, raça, passado, pátria e tradição, e irredutível a um fazer, competência ou função - basta-lhes ser o que são porque todas as suas práticas valem o que vale seu autor, sendo a afirmação e a perpetuação da essência em virtude da qual elas são realizadas. (BOURDIEU, 2008, p.2728)
\end{abstract}

Os profissionais da música são definidos pelos títulos que possuem e, de certa forma, esta prática fica aliada à representação daquilo que se estabelece ao serem mencionados nos discursos sociais. Todo esse processo simbólico separa o tocador e o músico em campos de significados e valores, simplesmente pelo estatuto de desvalorização "de autodidata e substituto" (BOURDIEU, 2008, p.28). O discurso produzido que prevê a superioridade e a inferioridade respectivamente, é encontrado na narrativa em análise, nela há o olhar voltado à separação hierárquica. Entretanto, ao mesmo tempo e na voz do nosso entrevistado há a certeza da importância das suas práticas para a manutenção de expressões culturais, que de certa forma não são legitimadas por tratar de conhecimentos acumulados através do esforço autodidata adquirido longe do "controle da instituição" encarregada do reconhecimento oficial e da aprendizagem dos saberes musicais. Esse poder dado à instituição garante uma contínua ideia simbólica de que aquele que não possui a formação é inferior ao que a possui. A produção de diferenças "oficiais" alimenta a crença da necessidade de possuir uma formação no campo escolar para garantir o reconhecimento e a legitimidade, mas não impede de haver uma contínua expressão cultural nos seringais e centros urbanos na Amazônia Acriana. $\mathrm{O}$ 
resultado da dicotomia entre o tocador e o músico, afasta uma situação real (representada pelo tocador) e uma situação ideal (representada pelo músico acadêmico).

Nesse contexto, torna-se importante esta pesquisa que traz à tona as lembranças de situações envolvendo a música do cotidiano (sem regras e métodos formais e sem preocupação com os reconhecimentos acadêmicos), pois as práticas culturais presentes explicitam trânsitos decoloniais na Amazônia Acriana. Diferente do que se prega no discurso oficial, são pessoas que não vivem isoladas em um espaço inóspito e desumanizado e que reproduzem formas de saber, ser, sentir, olhar suas culturas sem a necessidade de um resgate, uma vez que só se resgata o que está perdido. Voltemos às palavras de Seu Chiquinho:

Lembro de Mazurca, inclusive eu sei solar mazurca, sei solar rancheira, xerém, tem o xerém, que minha avó, a mãe da minha mãe, dançava o xerém, a mazurca é diferente da valsa, você ver uma pessoa dançar valsa, e toca uma mazurca, que se você não souber ele vai dançar a mazurca como valsa (Francisco Dalerbã em 10/03/2017).

No momento da entrevista, Seu Chiquinho ressalta a diferença entre valsa e mazurca após ser questionado:

\footnotetext{
É pouca coisa, é no pinicado do toque, é da dança também, minha avó dançava mazurca assim, que nem uma carrapeta, ela dançava muito bem. E assim por diante. Eu me criei assim, e dou glória a Deus por isso, hoje estou contando essa história, que muitos não teve a oportunidade de chegar a esse ponto, pra contar também, da minha época, né? (Francisco Dalerbã em 10/03/2017).
}

$\mathrm{Na}$ fala do músico é possível identificar que as expressões culturais no campo da dança e música interagiam com diversas influências, tinham suas características específicas e diferenciações, como uma forma de rever aquilo que era exterior aceitando ou rejeitando as influências.

Convém ressaltar as palavras de Seu Chiquinho, feliz por contar sua história, em que a música atravessa a vida e a vida é dedicada à música. Acompanhamos na sua narrativa oral o "ser" músico naquele espaço experienciado, portanto deslocamos o "nosso olhar" distanciando-nos do representativo usual sobre a cultura no seringal, com isso conseguimos "ver" no cotidiano e nas relações existentes, as experiências musicais partilhadas e acomodadas, a ruptura com instituições oficializadas e a persistência de uma expressão musical resistir e existir demarcando seu território.

\section{Trânsitos decoloniais: à guisa de conclusão}


As narrativas de Seu Chiquinho, em seus trânsitos entre universos culturais os mais distintos, são ouvidas na perspectiva de que a identidade ultrapassa a "raiz" e devido à relação cultural adquire um significado de multiplicidade, de forma a contribuir para a assimilação do novo e do outro em fragmentos de ações que constituirão um mosaico cultural a partir das trocas e relações (GLISSANT, 2011).

Portanto, cabe assinalar o cuidado necessário ao uso de expressões como "Amazônia acriana" ou "músicos acrianos" neste texto, por conta das trajetórias de produção de uma "pesada crosta de discurso" (CALVINO, 2006, p. 143), tomadas as palavras de Ítalo Calvino, sobre as Amazônias e às formas de subjetividade por elas geradas (ALBUQUERQUE, 2016).

Nessa mesma perspectiva, Durval Muniz propõe a tentativa de superar estereótipos imagéticos e discursivos acerca do Nordeste, por meio da procura das relações de poder e saber que produziram essas imagens e enunciados clichês, pois "tanto o discriminado como o discriminador são produtos de efeitos de verdade, emersos de uma luta e mostram os rastros dela" (ALBUQUERQUE JÚNIOR, 2009 p. 31). O Nordeste é tomado em seu trabalho como invenção pela repetição regular de enunciados tidos como definidores do caráter de uma região e de seu povo, mergulhados na emergência da formação discursiva nacional-popular e do dispositivo das nacionalidades, em torno dos quais se desenvolveu grande parte da historiografia brasileira, mas também das artes e outros saberes. O processo de construção imagética do Nordeste na obra de Durval Muniz é semelhante à construção de representações utópicas sobre a Amazônia a partir do olhar externo do colonizador que almejava a conquista do Novo Mundo. Nesse contexto, surgem as primeiras impressões envolvendo o exótico e o diferente capazes de construir as representações que se propagaram nas literaturas de viagem e outros textos presentes na intelectualidade e nos discursos políticos, envolvendo uma perspectiva de desenvolvimento necessário e ocupação dos espaços vazios. Entretanto, tais reações distanciam-se do real e fixam-se apenas na maneira como o europeu, ou o "outro" delimitou a Amazônia no decorrer da história, olhar que se consolidou até a atualidade.

O discurso hegemônico construído com a presença do outro no território amazônico desenvolve uma relação de poder simbólico (BOURDIEU, 2003) que impõe uma visão e representação, tendo como modelo comparativo aquilo que tem como ideal, urbanizado, e por fim superior. As representações são e foram construídas a partir de uma forma de olhar daquele que acreditava em uma superioridade racial, deixando fluir em seus discursos as diferenças que separavam o mundo "civilizado" do mundo primitivo. Através desses processos discursivos há a legitimação e imposição da representação do dominador 
caracterizando o controle de um sobre o outro, de forma que há uma "reiteração" (BOURDIEU, 2003) do discurso que se estende na história que trata do contexto amazônico.

Nesse ponto, a produção do filósofo Michel de Certau conduz à reflexão sobre os usos da língua em uma "economia escriturística", capitalista e conquistadora, com ênfase nas relações de poder que escrevem leis nos corpos individual e social (CERTEAU, 2011). Ao analisar as operações que envolvem a leitura, deixa de lado uma "ideologia do consumoreceptáculo" para chamar atenção para o fato de já existir, "multiforme embora sub-reptícia ou reprimida, outra experiência que não é a da passividade" (CERTEAU, 2011 p. 268) criando outros significados distintos daqueles instituídos pelas elites produtoras de linguagem, mesmo mergulhados no discurso por elas produzido. Faz-se necessário, portanto, estender o olhar sobre essas práticas e vislumbrá-las politizáveis, um exercício de ajuste das lentes em sintonia com a perspectiva decolonial da construção do conhecimento.

Nesse sentido, este texto busca ativar um alerta aos imaginários construídos a partir desta indústria escriturística à qual se refere Certeau. Portanto, atribuir nomes e qualificar as práticas com as quais dialogamos continua uma questão em aberto, com perguntas sem resposta, ambiguidades e contradições, portanto, um exercício criativo de desaprendizado dos mecanismos hegemônicos de dominação.

Neste texto são analisadas as perspectivas de construção do conhecimento de forma autodidata e inserida nas práticas culturais cotidianas, em relações sociais capazes de trincar ou corromper a lógica dicotômica entre floresta e cidade. Na esteira dessa reflexão, caem por terra outras categoriais coloniais em prol da valorização das vozes e experiências emergentes dessas práticas, em um exercício de diálogo que Mignolo (2010) caracterizou como "desobediência epistêmica".

Acenando para uma finalização de ideias, ressaltamos que quando se pensa a Amazônia, é possível levar o imaginário a um modelo teórico de homem determinado e devorado pela natureza grandiosa e desumanizada. Entretanto, faz-se oportuno compreender que as pessoas não estão/ou estiveram isoladas em um tempo e espaço. O seringal é/foi formado por pessoas que sempre desenvolveram trocas culturais simbólicas entre si, entre os "outros", entre o rural e o urbano, agregando e rejeitando.

Pensar um primeiro contato dos pesquisadores como a inauguração de uma relação ou a quebra de um isolamento, seria repetir, inclusive com as mesmas palavras, os mitos de fundação da "cultura amazônica", um discurso com o peso de uma arma de violência epistêmica, muitas vezes incorporada pela academia. Não se trata, portanto, de uma descoberta ou uma aproximação com objetivo de dar voz, mas de aprender como esses 
músicos compreendem a organização social em que vivem, nos caminhos de suas vidas atravessadas pela música.

É preciso estar atento aos fios que conectaram as pessoas envolvidas na pesquisa antes, para vislumbrar os trânsitos de saberes decoloniais, trajetórias de buscas e incertezas que levaram aos encontros em que floresceram os diálogos escritos.

E por mais que tentemos compreender, intelectualmente, analiticamente, os saberes referentes à vida ou à música de seu Chiquinho, não conseguimos, uma vez que os esteios que sustentam esse aprendizado estão em uma relação intuitiva com a música, ligada à contemplação do acontecimento musical, no qual o músico age como um receptor de sintonias, transformando-se ele próprio em instrumento, por onde a música flui, fluir esse capaz de criar brechas, que varam o muro do conhecimento letrado imposto como verdade.

\section{Referências}

ALBUQUERQUE, G. R. Acre. Em: ALBUQUERQUE, G. R. \& PACHECO, A. S. (orgs.) Uwakürü: dicionário analítico. Rio Branco: Nepan Editora, 2016. p. 13 - 29.

. Amazonialismo. Em: ALBUQUERQUE, G. R. \& PACHECO, A. S. (orgs.) Uwakürü: dicionário analítico. Rio Branco: Nepan Editora, 2016. p. 73 - 96.

ALBUQUERQUE, M. B. B. Espitemologia e saberes da Ayahuasca. Belém: EDUEPA, 2011.

ALBUQUERQUE JÚNIOR, D. M. A invenção do nordeste e outras artes. 4 ed. São Paulo: Cortez, 2009. 376 p.

BOURDIEU, P. A distinção: crítica social do julgamento. Tradução de Daniela Kern e Guilherme J. F. Teixeira. São Paulo: EDUSP. 2008.

Betrand Brasil, 2003.

O poder simbólico. Tradução de Fernando Tomaz, $6^{\mathrm{a}}$ ed. Rio de Janeiro:

CALVINO, I. A palavra escrita e a não-escrita. Em: AMADO, J. \& FERREIRA, M. M. (coord). Usos \& Abusos da História Oral. Rio de Janeiro: FGV, 2006. 304 p.

CERTEAU, M. A Invenção do Cotidiano: 1. Artes de fazer. 17. Ed. Petrópolis, RJ: Vozes, 2011. 316 p.

COUTO, A.C.N. Música Popular e Aprendizagem: algumas considerações. Revista Modus. Belo Horizonte. Ano V/ n 6. p. 55 - 68, maio 2008.

GLISSANT, E. Poética da Relação. Trad. Manuela Mendonça, Porto: AFRICA.CONT, 2011. 
LÓPEZ, I. Una genealogia alternativa: Para pensar la expressión músical en a latina. Em: PALERMO, Zulma (comp.). Arte y estética en la encrucijada descolonial. Buenos Aires: Ediciones del Signo, 2009.

MARTINS, A.J.S.; DIAS, J.O.; CUNHA, E.R. Desembarque no Aeroporto Velho: relato de experiências vividas no "Poeirinha" em Rio Branco-AC. Em: I CONGRESSO REGIONAL DE PESQUISA DO ESTADO DO ACRE E XXIV SEMINÁRIO DE INICIAÇÃO CIENTÍFICA DA UFAC. Rio Branco, 2015.

MESSINA, M. Atraso. Em: ALBUQUERQUE, G. R. \& PACHECO, A. S. (orgs.) Uwakürü: dicionário analítico. Rio Branco: Nepan Editora, 2016. p. 96 - 106.

MIGNOLO, W. 2010. Desobediência epistêmica: retórica de la modernidad, lógica de la colonialidade y gramática de la descolonialidad. Buenos Aires: Del Signo.

PORTELLI, A. Tentando aprender um pouquinho. Algumas reflexões sobre a ética na História Oral. Projeto História: Revista do Programa de Estudos Pós-Graduados em História e do Departamento de História da PUC-SP, São Paulo, Brasil, 1981, p. 13-33.

VIEIRA, J.L. Lambada das Quebradas Vol. II (1980) / Chantecler - Continental. 